Gelanggang Pendidikan Jasmani Indonesia

\title{
PENGARUH METODE DRILL DAN METODE BERMAIN TERHADAP HASIL BELAJAR PASSING SEPAKBOLA PADA PESERTA EKSTRAKURIKULER SEPAKBOLA USIA 16-17 TAHUN
}

\author{
Mohammad Fajar Syaifuddin ${ }^{1}$, Hariyoko $^{2}$, Usman Wahyudi $^{3}$
}

Universitas Negeri Malang, Jalan Semarang 5 Malang

\begin{tabular}{|c|c|}
\hline Info Artikel & Abstrak \\
\hline $\begin{array}{l}\text { Sejarah Artikel: } \\
\text { Diterima September } 2017 \\
\text { Disetujui Oktober } 2017 \\
\text { Dipublikasikan Desember } 201 \\
\text { Keywords: } \\
\text { metode drill, metode bermain, } \\
\text { hasil belajar passing } \\
\text { sepakbola. }\end{array}$ & $\begin{array}{l}\text { Tujuan penelitian ini adalah untuk mengetahui pengaruh metode drill dan metode } \\
\text { bermain terhadap hasil belajar passing sepakbola. Penelitian ini menggunakan } \\
\text { rancangan penelitian eksperimen. Subjek penelitian adalah } 14 \text { peserta ekstrakurikuler } \\
\text { MAN Kota Batu dan } 14 \text { peserta ekstrakurikuler SMKN } 11 \text { Malang. Analisis data } \\
\text { penelitian menggunakan teknik analisis varians satu jalur. Hasil pengujian hipotesis } \\
\text { didapatkan: (1) pembelajaran dengan perlakuan metode drill memberikan pengaruh } \\
\text { yang signifikan terhadap hasil belajar passing, (2) pembelajaran perlakuan metode } \\
\text { bermain memberikan pengaruh yang signifikan terhadap hasil belajar passing, dan (3) } \\
\text { ada perbedaan yang tidak signifikan antara pembelajaran dengan perlakuan metode } \\
\text { drill dan perlakuan metode bermain terhadap hasil belajar passing sepakbola peserta } \\
\text { ekstrakurikuler sepakbola usia } 16-17 \text { tahun. }\end{array}$ \\
\hline
\end{tabular}

(C) 2017 Universitas Negeri Malang

Alamat korespondensi:
E-mail: jayafajar33@gmail.com

\section{PENDAHULUAN}

Pada permainan sepakbola dibutuhkan komunikasi antar pemain untuk menjalin kerjasama yang baik dalam bermain sebagai kunci kesuksesan. Pemain sepakbola juga harus menguasai teknik dasar dalam bermain sepakbola. Menurut Herwin (2004: 21-24), menyatakan bahwa gerak atau teknik dasar permainan sepakbola meliputi gerak atau teknik tanpa bola dan gerak atau teknik dengan bola. Gerak atau teknik tanpa bola merupakan gerak tanpa menggunakan bola yang dilakukan dalam permainan sepakbola seperti berjalan, 
berjingkat, melompat, meloncat, berguling, berputar, berbelok, berkelit, dan berhenti tibatiba, sedangkan gerak atau teknik dengan bola merupakan gerak atau teknik dalam permainan sepakbola. Dengan menguasai teknik dasar bola yang meliputi kemampuan pengenalan bola dengan bagian tubuh (ball feeling), menendang bola (passing), menendang bola ke gawang (shooting), menggiring bola (dribling), menerima dan menguasai bola (receiveing and controlling the ball), menyundul bola (heading), gerak tipu (feinting), merebut bola (sliding tacklesliding), melempar bola kedalam (throw-in) dan menjaga gawang (goal keeping).

Memiliki passing yang akurat adalah harga mati bagi seorang pemain sepakbola (Scheunemann, 2005:31). Mengingat passing begitu sering dilakukan dalam sebuah pertandingan. Pelatih yang baik akan memulai tugasnya dengan memperbaiki kemampuan passing para pemainnya. Passing dalam permainan sepakbola bertujuan agar dapat mengoper bola dari satu teman ke teman lainnya sehingga memiliki ruang gerak yang sangat banyak. Pemain dapat melakukan pola penyerangan dan pola pertahanan dengan baik agar dapat mencetak goal ke dalam gawang.

Bermain merupakan peristiwa hidup yang sangat digemari oleh anak-anak maupun orang dewasa. Bermain merupakan suatu kebutuhan yang sangat penting di dalam kehidupan, bahkan bagi anak-anak hampir sebagian dari waktunya dihabiskan untuk bermain. Dengan bermain dapat dikembangkan kestabilan dan pengendalian emosi yang sangat penting bagi keseimbangan mental (Sudarsini, 2013:2).

Harsono (2015:81), menjelaskan bahwa pembelajaran drill teknik yaitu suatu keterampilan yang di ulang-ulang beberapa puluh kali (drill) akan dapat meningkatkan atau menguasai teknik tersebut. Jadi drill teknik mendominasi sesi-sesi latihan yang saat rutin. Metode bermain merupakan salah satu bentuk permainan sepakbola yang dilakukan di lapangan ataupun stadion. Ditinjau dari berbagai permainan sepakbola yang menggunakan metode bermain, passing merupakan hal yang paling sering digunakan dalam latihan dibandingan dengan teknik lainnya. Melalui passing akurat dan baik dapat menjalin kerja sama tim yang sangat kompak. Berkaitan dengan permasalahan penelitian, metode bermain disini dimaksudkan ingin meningkatkan teknik dasar passing dengan bentuk permainan (metode bermain dengan teknik khusus passing).
Metode drill dan metode bermain tersebut, masing-masing memiliki kelebihan dan kelemahan, sehingga belum dapat diketahui metode mana yang lebih efektif terhadap kemampuan peningkatan passing dalam permainan sepakbola. Untuk mengetahui metode peningkatan mana yang lebih efektif antara metode drill dan metode bermain terhadap kemampuan hasil belajar passing dalam permainan sepakbola, maka perlu dikaji dan diteliti melalui penelitian eksperimen.

Upaya mengetahui dan menjawab permasalahan yang muncul dalam penelitian, peningkatan passing dengan metode drill dan metode bermain ini dieksperimenkan pada peserta putra MAN Kota Batu Tahun ajaran 2016/2017. Sejauh ini proses pembelajaran pendidikan jasmani dan kesehatan di MAN Kota Batu khususnya permainan sepakbola (teknik dasar passing) belum menunjukkan hasil yang maksimal, sehingga perlu ditingkatkan. Seringkali peserta belum memahami dan mengerti teknik dasar awal passing itu seperti apa, passing yang kurang tepat pada sasaran, sulit dikontrol oleh teman sekelompoknya, bolanya sering agak melambung ke atas dan lain -sebagainya. Kesalahan-kesalahan yang dilakukan oleh peserta perlu ditelusuri faktor penyebabnya, apakah faktor teknik yang masih rendah, apakah faktor kelelahan, ataupun faktor kemampuan fisik dan lain sebagainya.

Melalui penelitian ini dapat meningkatkan penguasaan teknik passing sepakbola yang benar, sehingga dapat mendorong keterampilan sepakbola menjadi lebih baik dari sebelumnya. Melalui metode drill, siswa dapat diharapkan melakukan gerakan passing secara berulang-ulang, secara otomatis gerakan passing dapat dilakukan dengan baik dan benar. Disisi lain metode bermain bertujuan jika bermain sepakbola itu tidak memerlukan lapangan yang besar seperti sepakbola pada umumnya. Hal ini karena tidak hanya lapangan besar yang menjadi prioritas dalam melakukan latihan, menggunakan lapangan kecil dapat mengoptimalkan keterampilan yang ingin ditingkatkan secara terstruktur dengan baik. Melalui penelitian ini maka akan diketahui metode mana yang dapat mempengaruhi kualitas keterampilan secara baik dan efektif antara metode drill dan metode bermain terhadap peningkatan kemampuan passing dalam permainan sepakbola.

Centhini \& Russel (2009:2), menyatakan bahwa sepakbola dimainkan oleh dua regu dengan masing-masing regu terdiri dari 11 anggota termasuk penjaga gawang. Lamanya permainan dua babak $(2 \times 45$ menit) 
dengan 15 menit istirahat. Bola dimainkan dengan seluruh anggota badan kecuali tangan. Setiap tim harus mempunyai jumlah anggota pemain yang sesuai dengan yang dimainkan jika dalam permainan tim tersebut masih tidak memenuhi jumlah pemain maka dapat dinyatakan bahwa pertandingan tersebut akan dihentikan dan dimenangkan oleh tim yang mempunyai anggota pemain yang lengkap.

Sutristomi \& Sudarso (2014:571), menyatakan bahwa proses belajar merupakan kegiatan mental yang tidak dapat dilihat artinya proses perubahan yang terjadi dalam diri seseorang yang belajar tidak dapat kita saksikan. Perubahan tersebut dapat kita lihat dari adanya gejala-gejala perubahan perilaku yang tampak, macam-macam bentuk pengalaman sosial. Pengalaman mental dapat berupa membaca buku, mendengarkan ceramah, dan menonton TV atau film. Pengalaman fisik memanfaatkan seluruh indera ketika menggali informasi yang berupa pengamatan, percobaan, penelitian, kunjungan, study tour, pembuatan buku harian. Sedangkan pengalaman tersebut dapat berupa wawancara, bermain peran, diskusi, kerja bakti, pameran dan lain-lain.

Pembelajaran atau instruksional adalah suatu konsepsi dari dua dimensi kegiatan (belajar dan mengajar) yang harus direncanakan penguasaan sejumlah kompetensi dan indikatornya sebagai gambaran hasil belajar (Supriade, 2012:9). Menurut Sagala dalam Supriadie (2005:9), menyatakan bahwa pembelajaran adalah suatu proses dimana lingkungan seseorang secara sengaja dikelola untuk memungkinkan ia turut serta dalam tingkah laku tertentu dalam kondisi-kondisi khusus atau menghasilkan respons terhadap situasi tertentu.

Riyadi (2011:2), menyatakan bahwa belajar gerak adalah belajar yang diwujudkan melalui respon-respon muscular yang diprediksikan dalam gerakan tubuh atau bagian tubuh, yang merupakan sarana untuk mencapai tujuan belajar yang tercakup di dalam domain psikomotor. Menurut Rosdiani (2012:121), berpendapat bahwa belajar gerak yaitu studi tentang faktor-faktor yang mempengaruhi cara memperoleh keterampilan gerak oleh individu dan menampilkan keterampilan geraknya. Prestasi belajar gerak dapat diartikan sebagai tingkat kemampuan gerak tubuh yang dicapai melalui usaha belajar dan berlatih gerak, belajar gerak merupakan kegiatan belajar dimana gerakan tubuh merupakan titik sentral dari kegiatan yang dilakukan oleh pelajar (Sugiyanto \& Sujarwo, 1991:307).
Menurut Sudjana (2012:22), menyatakan bahwa hasil belajar adalah kemampuankemampuan yang dimiliki oleh siswa setelah ia menerima pengalaman belajarnya. Hasil belajar merupakan hasil dari suatu interaksi tindak belajar dan tindak mengajar, dari sisi guru tindak mengajar diakhiri dengan proses evaluasi hasil belajar sedangkan dari sisi siswa hasil belajar merupakan berakhirnya penggal dan puncak (Dimyati, 1998:3).

Dari beberapa pendapat ahli tersebut dapat disimpulkan bahwa pembelajaran yang baik dan efektif dapat meningkatkan hasil belajar siswa secara efektif. Pembelajaran tidak hanya memberikan pengetahuan, teori-teori, konsep-konsep akan tetapi lebih dari itu, agar dalam proses pembelajaran peserta didik dapat mengembangkan sejumlah potensi yang dia miliki dalam proses pembelajaran gerak.

Permainan sepakbola merupakan permainan beregu yang memerlukan dasar kerjasama antara anggota regu, sebagai salah satu ciri khas dari permainan sepakbola (Firzani, 2010:21). Untuk bisa bermain sepakbola dengan baik dan benar para pemain perlu menguasai teknik-teknik dasar sepakbola. Pemain yang memiliki teknik dasar yang baik, cenderung dapat bermain sepakbola dengan baik juga. Teknik-teknik dasar dalam permainan sepakbola ada beberapa macam seperti stop ball (menghentikan bola), shooting (menendang bola ke gawang), passing (mengumpan), heading (menyundul bola), tackling (merebut bola) dan dribbling (menggiring bola).

Subardi \& Setyawan (2007:13), sepakbola merupakan permainan tim. Keterampilan individu sesekali dapat ditunjukkan pada saat tertentu. Seorang pemain sepakbola berkualitas memiliki teknik individu yang baik, mental yang bagus, pengertian tentang permainan yang memadai, dan fisik yang mendukung.

Dari beberapa pendapat ahli tersebut dapat disimpulkan bahwa teknik dasar sepakbola adalah suatu yang wajib untuk dipelajari terlebih dahulu karena pemain ataupun atlet harus mampu menguasai seluruh teknik dasar sepakbola mulai dari passing, control, heading, shooting, dan dribbling. Seorang pemain sepakbola berkualitas memiliki teknik individu yang baik, mental yang bagus, pengertian tentang permainan yang memadai, dan fisik yang mendukung.

Passing merupakan seni dalam memindahkan momentum bola dari satu pemain ke pemain lain. Dengan passing yang baik, kamu akan dapat berlari ke ruang yang terbuka dan mengendalikan permainan saat 
membangun strategi penyerangan (Mielke, 2007:19).

Sutristomi \& Sudarso, (2014:571), menjelaskan bahwa "Sepakbola sejatinya adalah permainan tim. Walaupun pemain yang memiliki keterampilan tinggi bisa mendominasi pada kondisi tertentu, seseorang pemain sepakbola harus saling bergantung pada setiap anggota tim untuk menciptakan permainan cantik dan membuat keputusan yang tepat. Agar bisa berhasil dalam lingkungan tim ini, seorang pemain bola harus mengasah ketrampilan passing".

Passing yang akurat adalah harga mati bagi seorang pemain sepakbola. Mengingat passing begitu sering dilakukan dalam sebuah pertandingan (Scheunemann, 2005:33).

Dari beberapa pendapat ahli tersebut dapat disimpulkan bahwa passing adalah istilah yang berkaitan dengan aktivitas mengoper atau mengumpan bola ke arah teman. Passing adalah teknik mengoper atau memindahkan momentum bola dari satu pemain ke pemain lainnya dalam pertandingan sepakbola. Teknik passing sangat-sangat perlu dikuasai oleh pemain bola agar pola permainan yang diinginkan bisa berhasil baik dalam menyerang atau bertahan. Penguasaan bola dalam permainan sepakbola tersebut, pemain dituntut agar dapat melakukan berbagai keterampilan dasar dalam bermain. Salah satu diantaranya dengan melakukan berbagai pendekatan.

Metode drill atau sering juga disebut juga dengan metode latihan. Metode drill merupakan bentuk latihan yang berpusat pada guru atau pelatih. Semua kegiatan dalam pembelajaran diorganisasi oleh guru dan siswa mempraktikkannya sesuai dengan instruksi atau petunjuk dari guru atau pelatih. Menurut Harsono (2015:81), menjelaskan bahwa pembelajaran drill teknik yaitu suatu keterampilan yang di ulang-ulang beberapa puluh kali (drill) akan dapat meningkatkan atau menguasai teknik tersebut. Jadi drill-drill dapat menghasilkan pembelajaran atau penguasaan yang sempurna dalam beberapa aspek teknik yang akan dipelajari. Jadi kalau ingin belajar olahraga itu, lakukanlah seperti kau bermain olahraga itu, jangan sepotong-sepotong, artinya, jangan dengan cara menguasai dulu atau "membuang" waktu terlalu sering pada pembelajaran teknik-teknik dasarnya dulu sebelum melakukan permainan itu.

Sudjana (2014:86), menjelaskan bahwa metode latihan drill pada umumnya digunakan untuk memperoleh suatu ketangkasan atau keterampilan dari apa yang telah dipelajari. Mengingat latihan ini kurang mengembangkan bakat atau inisiatif siswa untuk berfikir, maka hendaknya guru atau pengajar memperhatikan tingkat kewajaran dari metode ini. Latihan (drill) adalah upaya untuk memantapkan keterampilan-keterampilan otomatis atau asosiasi yang telah diperoleh (Hamalik, 2012:97).

Drill secara denotatif merupakan tindakan untuk meningkatkan keterampilan dan kemahiran. Sebagai metode pembelajaran, drill adalah cara dalam proses pembelajaran siswa untuk mengembangkan kemahiran dan keterampilan, serta dapat pula untuk mengembangkan sikap dan kebiasaan. Latihan dan berlatih merupakan proses belajar dan membiasakan diri agar mampu melakukan sesuatu (Supriadie, 2012:149).

Dari beberapa pendapat ahli tersebut dapat disimpulkan bahwa metode drill yaitu latihan yang dilakukan secara berulang-ulang agar meningkatkan teknik tersebut dengan bertahap, karena dalam proses pembelajaran dapat memperoleh ketangkasan dalam meningkatkan keterampilan dan kemahiran dengan baik. Dilihat dari aspek teknik metode drill yang dilakukan oleh peserta, maka diperlukan metode bermain yang tepat dalam pelaksanaan pembelajaran.

Bermain merupakan peristiwa hidup yang sangat digemari oleh anak-anak maupun orang-orang dewasa. Bermain merupakan suatu kebutuhan yang sangat penting di dalam kehidupan, bahkan bagi anak-anak hampir sebagian dari waktunya dihabiskan untuk bermain. Dengan bermain dapat dikembangkan kestabilan dan pengendalian emosi yang sangat penting bagi keseimbangan mental (Sudarsini, 2013:2). Latihan bermain adalah kegiatan yang diambil dari situasi dalam permainan atau pertandingan (Muhajir, 2013:5). Menurut Aliyati (2013:6), berpendapat bahwa bermain adalah kegiatan jasmani yang dilakukan secara sukarela namun tetap pada aturan yang akan menghasilkan kesenangan.

Dari beberapa pendapat ahli tersebut dapat disimpulkan bahwa metode bermain adalah suatu metode pembelajaran dengan cara melakukan gerakan-gerakan fisik atau jasmani anak dalam rangka mengembangkan otot-otot. Agar dapat mengembangkan berbagai aspek menstimulasi tumbuh-kembang, kesenangan yang dapat membentuk proses kepribadian anak dan membantu anak dalam mencapai perkembangan fisik, intelektual, sosial, moral dan emosional.

Hermawan dkk, (2008:12.4-12.6) menyatakan bahwa ekstrakurikuler adalah kegiatan yang yang dilaksanakan di luar jam pelajaran 
biasa dan waktu libur sekolah dilakukan baik di sekolah ataupun di luar sekolah. Program kurikuler, pada hakikatnya adalah upaya untuk mempersiapkan siswa untuk memiliki kemampuan intelektual, emosional, spiritual, dan kompetensi sosial.

Halim (2013:5), menjelaskan bahwa kegiatan ekstrakurikuler adalah kegiatan di luar jam pelajaran sekolah yan merupakan kegiatan tambahan untuk pengembangan diri dan menyalurkan bakat dan minat sesuai dengan program latihan yang telah dibuat oleh pembina kegiatan ekstrakurikuler tersebut. Menurut Muhtar (2011:58), menyatakan bahwa kegiatan ekstrakurikuler olahraga besar manfaatnya dalam berbagai kegiatan yang digemari oleh peserta didik, khususnya dalam bidang olahraga permainan. Oleh karena itu pelaksanaan program ekstrakurikuler olahraga harus disesuaikan dengan kebutuhan setiap peserta agar tujuan yang diharapkan dapat tercapai dengan baik.

Patimah (2011:1) menyatakan bahwa ekstrakurikuler dapat diartikan sebagai kegiatan pendidikan yang dilakukan di luar jam pelajaran tatap muka, Dengan kata lain, ekstrakurikuler merupakan kegiatan pendidikan di luar jam pelajaran yang ditujukan untuk membantu perkembangan peserta didik, sesuai dengan kebutuhan, potensi, bakat, dan minat mereka melalui kegiatan yang secara khusus diselenggarakan oleh pendidik dan tenaga kependidikan yang berkemampuan dan berkewenangan di sekolah.

Dari beberapa pendapat ahli dapat disimpulkan bahwa kegiatan ekstrakurikuler merupakan sebuah upaya untuk melengkapi kegiatan kurikuler yang berada di luar jam pelajaran yang dilakukan di dalam lingkungan sekolah maupun di luar lingkungan sekolah guna melengkapi pembinaan manusia seutuhnya dalam hal pembentukan kepribadian para siswa.

Berdasarkan fakta mengenai keberhasilan penelitian metode drill dan metode bermain yang sudah cukup banyak dilakukan, salah satu diantaranya yaitu penelitian yang dilakukan oleh Hartono Suryo 2010 tentang judul "Pengaruh Pembelajaran Passing Sepakbola Antara Pendekatan Drill dan Pendekatan Bermain Futsal Pada Siswa Putra kelas VIII SMP Negeri 2 Wonogiri Tahun ajaran 2009/2010" menyimpulkan bahwa metode drill dapat meningkatkan hasil pembelajaran passing sepakbola. Berdasarkan latar belakang yang telah dipaparkan, maka peneliti melakukan penelitian dengan judul "Pengaruh Metode Drill dan Metode Bermain terhadap Hasil
Belajar Passing Sepakbola Peserta Ekstrakurikuler Sepakbola Usia 16-17 Tahun".

Tujuan Penelitian ini adalah : (1) Untuk mengetahui pengaruh metode drill terhadap hasil beajar keterampilan passing sepakbola. (2) Untuk mengetahui pengaruh metode bermain terhadap hasil belajar passing sepakbola. (3) untuk mengetahui perbedaan pengaruh pembelajaran metode drill dan metode bermain terhadap hasil belajar passing sepakbola.

\section{METODE}

Berdasarkan permasalahan yang akan diteliti, maka rancangan yang digunakan dalam penelitian ini berupa matching pretest-posttest comparison group design. Variabel bebas yang dimanipulasikan dalam penelitian ini adalah metode drill dan metode bermain, sedangkan untuk variabel terikatnya adalah keterampilan passing sepakbola.

Subjek penelitian ini adalah peserta ekstrakurikuler man kota batu yang berjumlah 14 peserta dan peserta ekstrakurikuler sepakbola smkn 11 malang yang berjumlah 14 peserta. Kelompok eksperimen jumlah keseluruhan terdiri dari 28 peserta yang akan dibagi menjadi 2 kelompok penelitian drill dan metode bermain, 14 peserta masuk dalam kelompok perlakuan metode drill dan 14 peserta masuk dalam kelompok perlakuan metode bermain. Setiap kelompok perlakuan masingmasing melakukan latihan 3 kali latihan dalam seminggu dengan hari yang berbeda.

Instrumen yang akan digunakan yaitu tes keterampilan sepakbola yang disusun oleh irianto (1995:9) pada bagian "melakukan passing rendah menuju sasaran", yaitu gawang kecil yang berbentuk bidang yang menjadi sasaran dengan ukuran lebar 1,5 $\mathrm{m}$ dan tinggi pancang $0,5 \mathrm{~m}$ dengan jarak penendang dari gawang $9 \mathrm{~m}$ dan garis di belakang gawang juga $9 \mathrm{~m}$ dan garis batas sah 1,5 m. Validitas tes tersebut adalah 0,812 dan reliabilitas sebesar 0,856 . Instrument tes yang digunakan berupa expsperimen dan tes keterampilan dasar sepakbola. Pada penelitian ini, pengumpulan data berupa tes keterampilan teknik dasar sepakbola, dokumentasi dan tes keterampilan passing sepakbola. Adapun tahap-tahap dalam pengumpulan data meliputi tahap persiapan, tahap pelaksanaan, dan pelaporan hasil pengumpulan data. Berikut adalah masingmasing dari tahap tersebut.

Berdasarkan tujuan penelitian yang telah dikemukakan dan dengan pertimbangan jenis data kuantitatif bentuk data rasio, maka teknik 
analisis data yang digunakan dalam penelitian ini adalah analisis varian satu jalur (one way anova) yaitu untuk menguji perbedaan dua mean distribusi atau lebih. Dalam penelitian ini analisis yang digunakan dalam menghendaki data berdistribusi normal dan homogen, sehingga dilakukan uji prasyarat. Adapun langkah-langkah analisis varians satu jalur sebagai berikut.

Teknik yang digunakan untuk analisis uji normalitas data adalah teknik lilliefors (suryono, 2014:93). Uji normalitas ini digunakan untuk mengetahui apakah data yang diperoleh berdistribusi normal atau tidak. Uji homo-genitas digunakan untuk mengetahui apakah kedua sampel yang diambil mempunyai varian populasi yang sama atau tidak. Untuk mengetahui homogenitas sampel dilakukan dengan menggunakan uji $\boldsymbol{F}_{\max }$ (sugiyono, 2011:175). Data yang dilakukan pengujian homogenitas adalah skor keterampilan antara tes awal dari masing-masing kelompok dan skor keterampilan antara tes akhir dari masing-masing kelompok. Data dinyatakan homogen apabila f hitung $<\mathrm{f}$ tabel, uji homogenitas ini dilakukan dengan taraf signifikasi $\alpha=0,05$ (kadir, 2016:165).

Uji hipotesis dilakukan dengan tehnik analisis satu jalur dengan taraf signifikasi $\alpha=$ 0,05 . Setelah uji normalitas dilakukan maka dilanjutkan dengan analisis data untuk menguji hipotesis. Teknik analisis data yang digunakan dalam penelitian ini adalah analisis varians satu jalur dengan taraf signifikan 0,05 ( $\alpha=0,05)$, teknik analisis varians ini digunakan untuk membandingkan beberapa kelompok obyek penelitian dari satu jenis variabel

\section{HASIL}

Data hasil tes keterampilan passing yang digunakan untuk analisis adalah skor tes awal (pretest) dan skor tes akhir (posttest) keterampilan passing peserta ekstrakurikuler sepakbola MAN Kota Batu dan SMKN 11 Malang. Deskripsi data hasil tes keterampilan passing tersebut disajikan pada Tabel 1.

Tabel 1. Deskripsi Hasil Belajar Passing sepakbola Peserta Ekstrakurikuler Sepakbola MAN Kota Batu dan SMKN 11 Malang

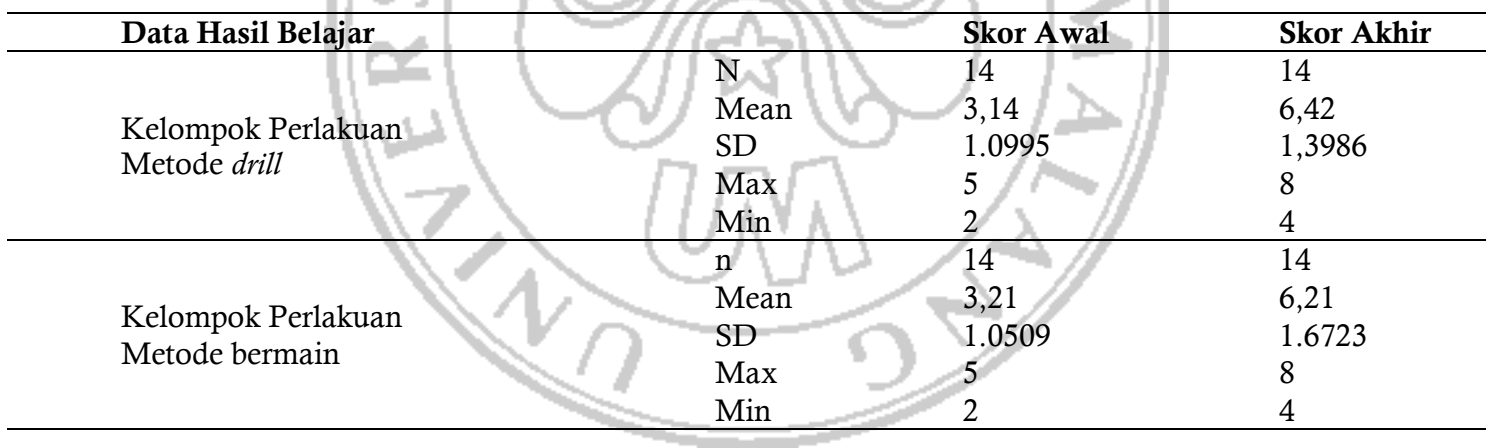

Keterangan:

n : Jumlah sampel setiap kelompok

mean : Rata-rata skor passing

SD : Simpangan baku

maks : Skor maksimal passing

min : Skor minimal passing

Dalam statistik parametrik, sebelum dilakukan pengujian hipotesis dengan analisis varian $(A N A V A)$ satu jalur, terlebih dahulu dilakukan uji persyaratan analisis varian, yaitu uji normalitas dan uji homogenitas. Tujuan uji normalitas adalah untuk mengetahui apakah distribusi sebuah data berdistribusi normal atau berdistribusi tidak normal. Uji normalitas dalam penelitian ini menggunakan uji Lilliefors pada taraf signifikansi $\alpha=0,05$. Uji normalitas skor keterampilan skor awal dengan skor akhir dilakukan terhadap keterampilan passing masing-masing kelompok. Perhitungan uji normalitas selengkapnya dapat dilihat pada lampiran uji normalitas.

Berikut adalah hasil rangkuman perhitungan uji normalitas dari masing-masing kelompok pembelajaran, yaitu skor tes awal dengan skor tes akhir keterampilan passing sepakbola dalam pembelajaran metode drill, 
dan skor tes awal dengan skor tes akhir keterampilan passing sepakbola dalam pembelajaran metode bermain dari kedua kelompok pembelajaran tersebut, dapat diketahui bahwa data hasil tes skor tes awal dengan skor tes akhir kedua kelompok pembelajaran tersebut berdistribusi normal, berikut ini sajian hasil perhitungan uji normalitas.

Berdasarkan hasil perhitungan uji normalitas yang ditunjukkan pada Tabel 4.6, uji normalitas skor tes awal hasil belajar keterampilan passing sepakbola kelompok perlakuan metode drill diperoleh hasil $\mathrm{L}_{\text {hitung }} 0,2056<$ $\mathrm{L}_{\text {tabel }}$ dengan taraf signifikansi $\alpha=0,05$ adalah 0,277 , uji normalitas skor tes akhir hasil belajar keterampilan passing sepakbola kelompok perlakuan metode drill diperoleh hasil $\mathrm{L}_{\text {hitung }} 0,1314$ $<\mathrm{L}_{\text {tabel }}$ dengan taraf signifikansi $\alpha=0,05$ adalah 0,277 , uji normalitas skor tes awal hasil belajar keterampilan passing sepakbola kelompok perlakuan metode bermain diperoleh hasil $\mathrm{L}_{\text {hitung }} 0,2181<\mathrm{L}_{\text {tabel }}$ dengan taraf signifikansi $\alpha$ $=0,05$ adalah 0,277 dan uji normalitas skor tes akhir hasil belajar keterampilan passing sepakbola kelompok perlakuan metode bermain diperoleh hasil $\mathrm{L}_{\text {hitung }} 0,1923<\mathrm{L}_{\text {tabel }}$ dengan taraf signifikansi $\alpha=0,05$ adalah 0,277. Maka dapat disimpulkan bahwa skor es awal hasil belajar keterampilan passing sepakbola dan skor tes akhir hasil belajar keterampilan passing sepakbola dari masing-masing kelompok berdistribusi normal.

Pengujian homogenitas adalah pengujian mengenai sama tidaknya variansi-variansi dua distribusi atau lebih. Uji homogenitas dalam penelitian ini menggunakan uji $\mathrm{F}$ pada taraf signifikansi $\alpha=0,05$. Uji homogenitas keterampilan passing awal dengan keterampilan passing akhir dilakukan terhadap keterampilan passing masing-masing kelompok. Perhitungan uji homogenitas selengkapnya dapat dilihat pada lampiran uji homogenitas.

Berikut adalah hasil rangkuman perhitungan uji homogenitas dari masing-masing kelompok pembelajaran, yaitu skor tes awal dengan skor tes akhir keterampilan passing

Tabel 2. Rangkuman Hasil Analisis Varian Skor Tes Hasil Belajar Keterampilan Passing Sepakbola Kelompok Perlakuan Metode Drill

\begin{tabular}{ccccccc}
\hline $\mathbf{S V}$ & $\mathbf{D k}$ & $\mathbf{J K}$ & $\mathbf{V}$ & $\mathbf{F}_{\text {hitung }}$ & $\mathbf{F}_{\text {tabel }}$ & Keputusan \\
\hline $\mathrm{T}$ & $28-1=27$ & 116,71 & - & & & \\
$\mathrm{A}$ & $2-1=1$ & 75,57 & 75.57 & 47,75 & 4,20 & $\mathrm{~F}_{\text {hitung }}>\mathrm{F}_{\text {tabel }}(47,75>4,20)$ \\
$\mathrm{D}$ & $28-2=26$ & 41,14 & 1,58 & & & \\
\hline
\end{tabular}

Keterangan:

$\mathrm{SV}=$ Sumber varians

$\mathrm{T}=$ Total

$\mathrm{A}=$ Antar kelompok sepakbola dalam pembelajaran metode drill, dan skor tes awal dengan skor tes akhir lajaran metode bermain dari kedua kelompok pembelajaran tersebut, dapat diketahui bahwa data hasil tes skor tes awal dengan skor tes akhir dan skor tes akhir kedua kelompok pembelajaran tersebut berdistribusi normal, berikut ini sajian hasil perhitungan uji homogenitas.

Berdasarkan hasil perhitungan uji homogenitas, skor tes awal dan akhir masingmasing kelompok diperoleh harga $F_{\text {hitung }} 1,62<$ $F_{\text {tabel }}$ dengan taraf signifikansi $\alpha=0,05=2,60$, skor tes awal dan akhir masing-masing kelompok diperoleh harga $F_{\text {hitung }} 2,53<F_{\text {tabel }}$ dengan taraf signifikansi $\alpha=0,05=2,60$, dan skor tes akhir dari kedua metode diperoleh harga $F_{\text {hitung }} 1,42<\quad F_{\text {tabel }}$ dengan taraf signifikansi $\alpha=0,05=2,60$. Sehingga dapat disimpulkan bahwa varian sampel tersebut homogen dan dapat dilanjutkan uji hipotesis menggunakan teknik anava satu jalur. Setelah dilakukan uji persyaratan analisis varians, yaitu uji normalitas dan uji homogenitas serta didapatkan hasil bahwa seluruh kelompok latihan berasal dari populasi yang berdistribusi normal dan homogen, selanjutnya akan dilakukan pengujian hipotesis dengan analisis varians (ANAVA) satu jalur.

Pengaruh Metode Drill terhadap Hasil Belajar Keterampilan Passing Sepakbola Peserta Ekstrakurikuler Sepakbola MAN Kota Batu Uji analisis varians satu jalur dalam penelitian ini menggunakan uji $\mathrm{F}$ pada taraf signifikansi $\alpha=0,05$. Pengujian hipotesis dengan analisis varians satu jalur dilakukan terhadap data skor tes keterampilan passing sepakbola awal dengan skor tes skor akhir keterampilan passing sepakbola kelompok perlakuan metode drill. Perhitungan uji analisis varians satu jalur selengkapnya dapat dilihat pada lampiran uji analisis varians satu jalur. keterampilan passing sepakbola dalam pembe- 
$\mathrm{D}=$ Dalam kelompok

$\mathrm{Dk}=$ Derajat kebebasan

$\mathrm{JK}=$ Jumlah kuadrat

$\mathrm{V}=$ Varians cuplikan

Berdasarkan hasil penelitian yang kemudian dilakukan perhitungan analisis varians satu jalur sebagaimana ditunjukkan dalam Tabel 2, diperoleh hasil harga $\mathrm{F}_{\text {hitung }}$ $47,75>F_{\text {tabel }}$ dengan taraf signifikansi $\alpha=0,05$ $=4,20$. Dengan hasil penelitian dan perhitungan dengan demikian dapat disimpulkan bahwa ada pengaruh yang signifikan antara hasil keterampilan passing sepakbola awal dengan keterampilan passing sepakbola akhir yang dilakukan di kelompok metode drill.

\section{Peserta Ekstrakurikuler Sepakbola SMKN 11 Kota Malang}

Uji analisis varians satu jalur dalam penelitian ini menggunakan uji $\mathrm{F}$ pada taraf signifikansi $\alpha=0,05$. Pengujian hipotesis dengan analisis varians satu jalur dilakukan terhadap data skor tes awal keterampilan passing sepakbola dengan skor tes akhir keterampilan passing sepakbola kelompok metode bermain. Perhitungan uji analisis varians satu jalur selengkapnya dapat dilihat pada lampiran uji analisis varians satu jalur.

\section{Pengaruh Metode Bermain terhadap Hasil} Belajar Keterampilan Passing Sepakbola

Tabel 3. Rangkuman Hasil Analisis Varians Skor Tes Hasil Belajar Keterampilan Passing Sepakbola Kelompok Perlakuan Metode Bermain

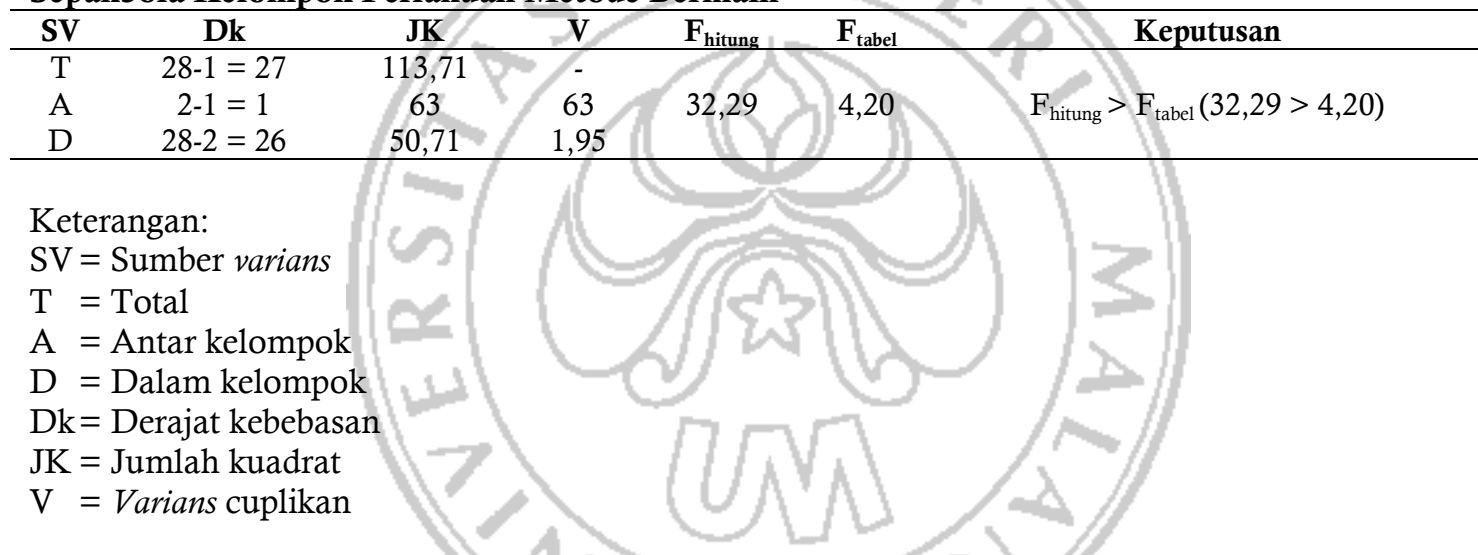

Berdasarkan hasil penelitian yang kemudian dilakukan perhitungan analisis varians satu jalur sebagaimana ditunjukkan dalam Tabel 3 , diperoleh hasil harga $F_{\text {hitung }}$ $32,29>\mathrm{F}_{\text {tabel }}$ dengan taraf signifikansi $\alpha=0,05$ $=4,20$. Dengan hasil penelitian dan perhitungan dengan demikian dapat disimpulkan bahwa ada pengaruh yang signifikan antara hasil keterampilan passing sepakbola awal dengan keterampilan passing sepakbola akhir yang dilakukan di kelompok metode bermain.

Perbedaan Pengaruh antara Metode Drill dan Metode Bermain terhadap Hasil Belajar
Keterampilan Passing Sepakbola Peserta Ekstrakurikuler Sepakbola MAN II Kota Batu dan SMKN 11 Malang

$\mathrm{Uji}$ analisis varians satu jalur dalam penelitian ini menggunakan uji $\mathrm{F}$ pada taraf signifikansi $\alpha=0,05$. Pengujian hipotesis dengan analisis varians satu jalur dilakukan terhadap data skor tes awal hasil belajar keterampilan passing dengan skor tes hasil akhir keterampilan passing. Perhitungan uji analisis varians satu jalur selengkapnya dapat dilihat pada lampiran uji analisis varians satu jalur. Ringkasan hasil perhitungannya ditunjukkan dalam Tabel 4 berikut ini

Tabel 4. Rangkuman Hasil Analisis Varians Skor Tes Akhir Hasil Belajar Keterampilan Passing Sepakbola Masing-masing Kelompok

\begin{tabular}{ccccccc}
\hline $\mathbf{S V}$ & $\mathbf{D k}$ & $\mathbf{J K}$ & $\mathbf{V}$ & $\mathbf{F}_{\text {hitung }}$ & $\mathbf{F}_{\text {tabel }}$ & Keputusan \\
\hline $\mathrm{T}$ & $28-1=27$ & 16,71 & - & & & \\
$\mathrm{A}$ & $2-1=1$ & 0,14 & 0,14 & 0,22 & 4,22 & $\mathrm{~F}_{\text {hitung }} \mathrm{F}_{\text {tabel }}(0,22<4,20)$ \\
$\mathrm{D}$ & $28-2=26$ & 16,57 & 0,63 & & & \\
\hline
\end{tabular}


Keterangan:

$\mathrm{SV}=$ Sumber varians

$\mathrm{T}=$ Total

$\mathrm{A}=$ Antar kelompok

$\mathrm{D}=$ Dalam kelompok

$\mathrm{Dk}=$ Derajat kebebasan

$\mathrm{JK}=$ Jumlah kuadrat

$\mathrm{V}=$ Varians cuplikan

Berdasarkan hasil perhitungan analisis varians satu jalur (one way anava) sebagaimana ditunjukkan dalam Tabel 4.10, diperoleh harga $\mathrm{F}_{\text {hitung }} 0,22<\mathrm{F}_{\text {tabel }}$ dengan taraf signifikansi $\alpha=$ $0,05=4,20$. Dengan demikian dapat disimpulkan bahwa ada perbedaan dari kedua metode tersebut antara selisih skor tes awal hasil belajar keterampilan passing sepakbola dengan skor tes akhir hasil belajar keterampilan passing sepakbola masing-masing kelompok pembelajaran.

\section{PEMBAHASAN}

Setelah dilaksanakan pemberian perlakuan dengan metode drill sebelum latihan selama 16 kali pertemuan (pembelajaran tiga kali dalam seminggu) dapat meningkatkan hasil belajar keterampilan passing sepakbola peserta ekstrakurikuler sepakbola MAN Kota Batu. Berdasarkan hasil penelitian terdapat pengaruh yang signifikan pembelajaran passing sepakbola dengan perlakuan metode drill terhadap hasil belajar keterampilan passing sepakbola.

Peningkatan hasil belajar keterampilan passing sepakbola pada kelompok perlakuan metode drill dikarenakan peserta dapat belajar dalam melakukan suatu teknik gerak dasar dengan cara sistem pengulangan secara bertahap yang ada di dalam metode drill (macammacam pembelajaran teknik dasar passing sepakbola) dan siswa senang akan pembelajaran. Roestiyah (2008:125), menyatakan bahwa "metode drill adalah suatu teknik yang dapat diartikan sebagai suatu cara mengejar dimana siswa melaksanakan kegiatan-kegiatan latihan, agar siswa memiliki ketangkasan atau keterampilan yang lebih tinggi dari apa yang telah dipelajari. Menurut Harsono (2015:81), menjelaskan bahwa pembelajaran drill teknik yaitu suatu keterampilan yang di ulang-ulang beberapa puluh kali (drill) akan dapat meningkatkan atau menguasai teknik tersebut.

Terdapat pengaruh metode drill dalam pembelajaran passing futsal (Deny, 2010), sehingga metode drill dikatakan lebih dominan bagi keterampilan passing yang dimiliki siswa putra kelas VIII SMP Negeri 2 Wonogiri.

Sebagai tindak lanjut dari penelitian terdahulu, peneliti telah melakukan penelitian dengan hasil terdapat pengaruh metode drill terhadap peningkatan hasil belajar keterampilan passing sepakbola yang dilakukan pada peserta ekstrakurikuler MAN Kota Batu.

Pengaruh Metode Bermain terhadap Hasil Belajar Keterampilan Passing Sepakbola Peserta Ekstrakurikuler Sepakbola SMKN 11 Malang

Pemberian perlakuan dengan metode bermain mendapatkan pertemuan yang sama yaitu selama 16 kali pertemuan (pembelajaran tiga kali dalam seminggu). Pendekatan menyeluruh dapat meningkatkan hasil belajar keterampilan passing sepakbola peserta ekstrakurikuler SMKN 11 Malang. Berdasarkan hasil penelitian terdapat pengaruh yang signifikan pemberian pembelajaran passing sepakbola dengan metode bermain terhadap hasil belajar keterampilan passing sepakbola siswa dengan peningkatan hasil belajar keterampilan passing sepakbola tersebut dikarenakan perlakuan metode bermain yang jelas akan materi yang telah disampaikan.

Peningkatan hasil belajar keterampilan passing sepakbola pada kelompok perlakuan metode bermain dikarenakan peserta dapat belajar dalam melakukan suatu teknik gerak dasar dengan cara bermain agar dapat mengembangkan tujuan pembinaan anak dalam mendapatkan hasil yang diharapkan yang terdapat di dalamnya yaitu (macammacam pembelajaran teknik dasar passing sepakbola) dan peserta senang akan pembelajaran yang akan disampaikan. Menurut Dewi (2014:4), menyatakan bahwa metode bermain adalah cara yang digunakan guru dalam menyampaikan ilmu yang tepat melalui hubungan dengan anak pada saat berlangsungnya pembelajaran sehingga menghasilkan pemahaman yang maksimal dengan mencapai kompetensi yang ditetapkan melalui aktivitas yang dipilih sendiri oleh anak tersebut dasar 
kesenangan bukan karena hadiah atau pujian tanpa pertimbangan hasil akhir. Latihan bermain adalah kegiatan yang diambil dari situasi dalam permainan atau pertandingan (Muhajir, 2013:5).

Terdapat pengaruh metode bermain terhadap peningkatan passing sepakbola, (Purwoko, 2015) sehingga metode bermain dikatakan lebih dominan bagi keterampilan passing yang dimiliki peserta ekstrakurikuler SDN Kepanjen 2 Jombang.

Sebagai tindak lanjut dari penelitian terdahulu, peneliti telah melakukan penelitian dengan hasil terdapat pengaruh metode bermain terhadap peningkatan hasil belajar keterampilan passing sepakbola yang dilakukan pada peserta ekstrakurikuler sepakbola SMKN 11 Malang.

Perbedaan Pengaruh antara Metode Drill dan Metode Bermain terhadap Hasil Belajar Keterampilan Passing Sepakbola Peserta Ekstrakurikuler Sepakbola MAN Kota Batu dan SMKN 11 Malang

Berdasarkan uji hipotesis, terdapat perbedaan pengaruh hasil belajar peserta antara peningkatan hasil belajar kelompok perlakuan metode drill dan peningkatan hasil belajar kelompok perlakuan metode bermain.-Berdasarkan nilai skor akhir hasil belajar keterampilan passing sepakbola, kelompok perlakuan dengan metode drill mendapat hasil belajar lebih tinggi daripada kelompok perlakuan metode bermain.

Hasil belajar keterampilan passing sepakbola dengan metode drill yang lebih tinggi dikarenakan dengan metode drill peserta dapat mengetahui dan mengamati suatu materi yang akan diberikan berserta penjelasan terhadap macam-macam latihan yang akan dilakukan secara tersruktur dan berulang-ulang, sehingga proses pembelajaran sangat jelas dan peserta paham akan materi yang telah disampaikan, sedangkan dalam perlakuan metode bermain penyampaian materi passing sepakbola yang kurang efektif dan kurang jelas dikarenakan macam-macam jenis latihan yang diberikan berupa bermain yang dapat dipertandingkan dengan satu kelompok yang sama. Penjelasan dalam pemberian materi yang cukup singkat, sehinga peserta hanya mengamati contoh yang diberikan lalu melakukan berbagai latihan tersebut dengan kurang maksimal dalam perlakuan.

Hasil penelitian yang dilakukan peneliti pada peserta ekstrakurikuler sepakbola MAN Kota Batu dan SMKN 11 Malang, Ada perbedaan pengaruh antara pemberian perlakuan dengan metode drill dan metode bermain terhadap hasil belajar passing sepakbola dari kedua metode tersebut.

\section{KESIMPULAN}

Berdasarkan hasil penelitian dan hasil analisis data yang telah dilakukan, dapat diperoleh kesimpulan sebagai berikut: (1) Ada pengaruh metode drill terhadap peningkatan hasil belajar keterampilan passing sepakbola peserta ekstrakurikuler sepakbola MAN Kota Batu, (2) Ada pengaruh metode bermain terhadap peningkatan hasil belajar keterampilan passing sepakbola peserta ekstrakurikuler sepakbola SMKN 11 Malang, (3) Ada perbedaan pengaruh peningkatan metode drill dan metode bermain terhadap hasil belajar keterampilan passing peserta ekstrakurikuler sepakbola MAN II Kota Batu dan SMKN 11 Malang

\section{DAFTAR PUSTAKA}

Centhini \& Russel. Buku Pintar Sepakbola. Jakarta: Penerbit Inovasi

Gifford, C. 2007. Keterampilan Sepak Bola. Yogyakarta: PT Citra Aji Kusuma.

Ganesha, 2010. Kutak-Katik Latihan Sepakbola Usia Muda. Jakarta: PT Visi Gala 2000.

Halim, 2013. Minat Siswi SMA Dr. Soetomo Surabaya Pada Kegiatan Ekstrakurikuler Futsal. Jurnal Penelitian, hlm. 5.

Hamalik, O. 2012. Kurikulum dan Pembelajaran. Jakarta: Bumi Aksara

Hermawan, dkk. 2008. Pengembangan Kurikulum dan Pembelajaran. Jakarta:

Universitas Terbuka Departemen Pendidikan Nasional..

Haryoko, S. 2009. Efektivitas Pemanfaatan Media Audio-Visual Sebagai Alternatif Optimalisasi Model Pembelajaran. Jurnal Edukasi@Elektro (Vol. 5, No 1, Maret 2009, hlm. 1-10)

Luxbacher, J.A.. 2008. Sepakbola: Langkahlangkah Menuju Sukses. Jakarta: PT Raja Grafindo Persada.

Luxbacher, J. A. 2004. Sepak Bola Jakarta: PT. Grafindo. 
Mielke, D. 2007. Dasar-dasar Sepakbola. Bandung: Pakar Raya.

Muhajir. 2014. Pendidikan Jasmani Olahraga dan Kesehatan.Malang: Penerbit Erlangga.

Muhtar, 2011. Kegiatan Ekstrakurikuler Olahraga Dalam peningkatan Gerak Dasar (Motor Ability) Siswa Sekolah dasar. Jurnal Pendidikan Olahraga, hlm. 56.

Mu'arifin. 2009. Dasar-Dasar Pendidikan Jasmani dan Olahraga. Malang; IKIP Malang.

Ma'mun \& Saputra. 2000. Perkembangan Gerak Dan Belajar Gerak. Departemen Pendidikan Dan Kebudayaan.

Patimah, 2011. Pendidikan Karakter Melalui Program Ekstrakurikuler. Jurnal Pendidikan Karakter, hlm. 1.

Purwoko \& Indriarsa. 2015. Pengaruh Penerapan Model Bermain Peran Terhadap Hasil Belajar Passing Sepak Bola SDN Kepanjen 2 Jombang. Jurnal Pendidikan Olahraga dan Kesehatan (Volume 03 Nomor 02 Tahun 2015, 473-478)

Roestiyah. 2008. Strategi Belajar Mengajar. Jakarta: PT. Balai Pustaka.

Rianto, 2006. Pendekatan, Strategi, Dan Metode Pembelajaran. Malang: PPPG IPS dan PMP Malang.

Riyadi. 2011. Pemrosesan Informasi Dalam Belajar Gerak. Jurnal ilmiah SPIRIT, ISSN; 1411- 8319 (Vol. 11 No. 2 Tahun 2011).

Suparno, dkk. 2010. Pedoman Penulisan Karya Ilmiah. Malang: Universitas Negeri Malang.

Sudjana, N. 2014. Dasar-Dasar Proses Belajar Mengajar. Bandung: Sinar Baru Algensindo.

Sutristomo \& Sudarso. 2015. Penerapan Modifikasi Bola Untuk Meningkatkan Hasil Belajar Passing Sepakbola Pada Siswa Kelas $V$ SDN Manukan Wetan II-555. Jurnal Pendidikan Olahraga dan Kesehatan (Volume 02 Nomer 03 Tahun 2014, 156 $-574)$.

Subardi \& Setyawan, 2007. SepakBola . Klaten: PT Macanan Jaya Cemerlang.

Sugiyanto \& Sudjarwo, 1991. Belajar Gerak. Jakarta:Penerbit Universitas Terbuka, Depdikbud.
Supriadie, D \& Darmawan, D. 2012. Komunikasi Pembelajaran. Bandung: PT Remaja Rosdakarya.

Subagyo I. 1995. Penyusunan Tes Keterampilan Bermain Sepakbola bagi Siswa Sekolah Sepakbola Puspor IKIP Yogyakarta. Yogyakarta: FPOK IKIP.

Sudarsini, 2013. Pendidikan Jasmani dan Olahraga. Malang: Perputakaan Um.

Scheunemann, 2005. Dasar-Dasar Sepak Bola Modern Malang: Penerbit Dioma.

Wardana \& Sudarso. 2015. Peningkatan Hasil Belajar Passing Pada Permainan Sepakbola Melalui Metode Pembelajaran Langsung Siswa Kelas V Sdn Tulangan Ii Sidoarjo. Journal Pendidikan Olahraga dan Kesehatan (Volume 03 Nomor 01 Tahun 2015, 147 - 153).

Witiyasari \& Muhammad. 2014. Peningkatan Hasil Belajar Siswa Materi Passing Sepakbola Melalui Model Pembelajaran Kooperatif Tipe Student Team Achievement Division (STAD) Di Kelas IV B SDIT Insan Kamil Sidoarjo. Jurnal Pendidikan Olahraga dan Kesehatan (Volume 02 Nomor 02 Tahun 2014, 236 - 242).

Yunus, M. 2013. Dasar-Dasar Permainan Sepakbola. Malang: Um Press 